\begin{tabular}{c} 
Volume and Issues Obtainable at Center for Sustainability Research and Consultancy \\
Journal of Business and Social Review in Emerging Economies \\
ISSN: 2519-089X (E): 2519-0326 \\
Volume 5: No. 1, June 2019 \\
CSRᄃ \\
Journal homepage: www.publishing.globalcsrc.org/jbsee \\
\hline
\end{tabular}

\title{
Restructuring and the Dilemma of State Police in Nigeria: to Be or Not to Be?
}

\section{${ }^{1}$ Badamasi Saidu, ${ }^{2}$ Zuwaira Haruna Rasheed, ${ }^{3}$ Ummu Atiyah Binti Ahmad Zakuan,${ }^{4}$ Kamarul Zaman Bin Haji Yusoff}

\author{
${ }^{1}$ School of International Studies Universiti Utara Malaysiaa; Federal University Birnin-Kebbi, Kebbi State \\ Nigeriab, Email adress: saidubadamasi@gmail.com \\ ${ }^{2}$ Waziru Umaru Federal Polytechnic Birnin-Kebbi, Kebbi-state Nigeria \\ ${ }^{3}$ School of International Studies, Universiti Utara Malaysia \\ ${ }^{4}$ School of International Studies, Universiti Utara Malaysia
}

\begin{tabular}{|c|c|}
\hline ARTICLE DETAILS & ABSTRACT \\
\hline $\begin{array}{l}\text { History } \\
\text { Revised format: May } 2019 \\
\text { Available Online: June } 2019\end{array}$ & $\begin{array}{l}\text { The success or otherwise of any police system lies in the institutional } \\
\text { structure upon which the institution is framed. As a federation, there is } \\
\text { need to stress for devolution of power through restructuring for effective } \\
\text { police system. This is necessary giving the heightened insecurity and }\end{array}$ \\
\hline $\begin{array}{l}\text { Keywords } \\
\text { Restructuring, State Police, } \\
\text { Constitution and the National } \\
\text { Police }\end{array}$ & $\begin{array}{l}\text { centralise nature of the police institution in the country. The over } \\
\text { centralisation of policing has made the institution to be control and } \\
\text { influence at the discretion of the political head as provided in section } 214 \\
\text { of the } 1999 \text { constitution as amended. On the other hand, giving the } \\
\text { political immaturity in Nigeria, decentralising the national policing to give }\end{array}$ \\
\hline $\begin{array}{l}\text { JEL Classification: } \\
G 34, H 71,\end{array}$ & $\begin{array}{l}\text { way to state police also has its own implication of over beardedness, } \\
\text { possible political influence of the governors against oppositions, poor } \\
\text { funding and formalisation of political thugs and party supports at the } \\
\text { detriment of the security business. In view of these therefore, effective } \\
\text { police system will be achieved through constitutional amendment of } \\
\text { section } 214 \text { by removing the discretional command of the political heads } \\
\text { which derogated. The institution should be place under justice system to } \\
\text { be govern by rule of law. }\end{array}$ \\
\hline
\end{tabular}

(C) 2019 The authors, under a Creative Commons AttributionNonCommercial 4.0

Corresponding author's email address: saidubadamasi@ gmail.com

Recommended citation: Saidu, B., Rasheed, Z. H., Zakuan, U. A. B. A. and Yusoff, K. Z. B. H. (2019). Restructuring and The Dilemma of State Police In Nigeria: To Be or Not To Be? Journal of Business and Social Review in Emerging Economies, 5 (1), 41-50

DOI: $10.26710 /$ jbsee.v5i1.554

\section{Introduction}

From the sectarian killings in Mambila and plateau, armed banditry and cattle rustling in Zamfara state, kidnapping in Birnin-gwari to continuing farmers-harder's crisis in Benue, Nasarawa and southern Kaduna state, Nigeria is witnessing a state of gruesome killings, and even the north-east continued to be ravaged by the activities of BokoHaram. For even those who have not been cut-off by this variety of security challenges, life isn't easy or straight forward. Jobs continued to be elusive for the young teaming population who are also continued facing harassment by the police special ant-rubbery squad (SARS). Nigeria's infant's mortality rate is one of the highest in the world losing 2300 children under the age of 5 a day (Kasali \& Odetola, 2016). Of those who survived, another 2.5million suffers from stunted growth annually due to lack of nutrition (Kasali \& Odetola, 2016). The catalogue of the 
problems facing the country is long, and there is no gang saying we are not where we should be as a nation. Things are not working, and some say is because of the way we are structured from big government that is too expensive and unwieldly exercising control over too many things to the autonomies of regions. These issues are some of the problems that many believed to be the reasons for the dysfunctionality of the Nigeria's state. For many therefore, according to Nwogwugwu \& Kupoluyi (2015) the answer lies with "restructuring".

Given the preceding, it is indisputable at present to state that Nigeria is bedevilled by multitudes of existential security challenges. The recent most recurring of the situation in a broader sense are Farmers-herders conflict, youth intolerant (unemployment), kidnapping, cyber-crime, insurgency, robbery, corruption, poverty increase and persistent attacks among communities (Nwogwugwu \& Kupoluyi 2015). Against this background, since independence in 1960, there was never time in the history of Nigeria when agitation for restructuring of the federation for fiscal federalism and by extension decentralisation of the Nigeria police force is not at stake, but the call for that is alarming at present due to the magnitude of these conflicts and the general insecurity in the land. The return to democratic governance in 1999 till date, has witnessed an increase in criminal violence due to freedom and liberty enjoyed by the Nigerian people (Eme \& Anyadike (2012). Evidently, the rate of the insecurity from 1999 to date, including kidnapping, militancy, ritualism, traffic in persons, Boko- Haram insurgency, child abuse, rape, motivated conflicts of ethnic and religious killings by unknown gunmen is graphically high. Other sources of the insecurity in the land include public disorder resulting from poor governance, economic down turn (recession), public mistrust and dishonesty by looting of public funds which has combinedly heightened the tarnished justice system and tensed the insecurity situation (Akume \& Godswil, 2016).

The existing security challenges have made Nigeria to be on the watch list of many countries as "unsafe zone" for businesses and tourism visitation. For instance, Adefi \& Anchor (2013) has predicted in 2014, on the likelihood of graphic increase in social unrest and disorder of the Nigerian state with high risk of uncertainty along other countries such as Egypt, Libya, Somalia, Yemen and Afghanistan. In different part of the country such as in the south-south, the militancy activities of various militia groups have scared away lots of foreign investors who moved to some neighbouring countries believed to be safer than Nigeria, Ochei in an interview with The Pointer (2018, July). In the north-eastern part of Nigeria states i.e. Borno, Adamawa and Yobe etc insurgency by the BokoHaramites have destroyed many lives and properties with broad day light terror in some major cities which have deserted local investors. Major commercial midpoints in the country such as Aba, Kano, Lagos and Port Harcourt are increasingly challenged with banditry in banks and financial centres, offices, shops and market areas with the recent occurrence of bank robbery in Offa town in Kwara State, Ogunbiyi interviewed by PM News (2018, July).

The increasing violent and non-violent security challenges in the country, for instance, the high proportion of cattlerustling, banditry and indiscriminate kidnapping in the north-western region of Kaduna and Zamfara states; and pastoralist/farmers clashes in north-central states of Benue, Plateau, Nasarawa, Taraba and southern Kaduna area; kidnapping and militancy in the south-east and south-south respectively has proven that safeguarding the vast Nigeria's landmass and its population growth of about 200million requires more security personnel and equipment's with knowledge of operating socio-cultural terrain to uproots the emerging criminalities. According to Ochei in an interview with The Pointer (2018, July) avers that "the situation has led to the establishment of various formal and informal security outfits known as 'vigilante groups' such as community neighbourhood guards, the village hunter's guild, and civilian Joint tax force, Karota, Lasma, Operation-Yaki and other security outfits recognised by various state governments to assist the Nigeria Police force. This justifies that, the Nigeria police force were overwhelmed and over stretched by the snowballing crime occurrences in different part of the country. Some of the above-mentioned security outfits for instance the first two, were village organised security outfits set up by various communities for self-defence combining local hunters and the warriors meant to support the strengthening of community security. Also, the emergence and spread of private security guards/enterprises due to denial of peace in institutions and urban communities by criminal's activities, are all to reinforce the effort of the Nigeria police force in its failure to the mounting security challenges in the country (Ochayi, Vanguard 2018, February). By constitution therefore, securing the lives and properties of the Nigerian citizenry is entrusted on the Nigeria police force which have all been ineffective based on the decimal and regular occurrences of crimes and insecurity in the Nigeria state. By this therefore Ehindero (2018) sees that the police have remained dishonourably defeated in the performance of their fundamental task entrusted to them by the constitution.

Going by this scenario of unfortunate development narrated above, it is argued by Aremu in interview with Punch (2018, March) that the Nigerian police force at present are inadequate in addition of been inefficient, under 
motivated, corrupt and lacks contemporary policing techniques to match with the modern crimes perpetrated on daily bases. It is on this bases that the public have a poor perception and low morale in their capability to curb the growing sophisticated crimes and insecurity in the country. Worst of it is that, the public see criminal elements in the force through their compromising attitudes and negligence of duty at the time when their service is needed (Innocent \& Ogbochie, 2014). The incapability of the current police system in the country is viewed by many Nigerians as due to centralisation of command structure and authority of the police force, with obvious call for decentralisation to give way for the creation of state police as an alternative approach to the disturbing crimes and wide spread insecurity in the country Enehikhuere interviewed by The News (2017, July).

This paper therefore, present and discussed on the issues revolving the creation of "state police" as a recourse to the growing insecurity in Nigeria. It starts with introduction and theoretical explanation, the antiquity of the Nigeria police-force, provision of the constitution, argument "for" and "against" state police, remarks and conclusion.

\section{The Concept of Restructuring and State Police}

Restructuring is viewed differently by different people. To some, it means creation of more states, while others is going back to regional arrangement to reduce cost of governance through duplication of offices. While to others it means the practice of 'true fiscal federalism' where the federating units will be able to finance itself independent of the federal support. Thus, according to Enegholase \& Onyeka Obetta interviewed by Vanguard (2012, August, restructuring could mean to be a culmination of enduring clamour by Nigerians for the country to function well. He therefore sees the present composition and structure in the country is not working as a nation. Furthermore, the country will benefit from restructuring in areas like resource ownership, job creation, debt management and enabling environment for investors, creation of state police by weakening the centre. In fact, Johnson (2014), posited a win-win situation for all Nigerians looking at the decentralisation of the police system deeply from security perspectives by making the federating units sustainable to have a local control regarding the public safety.

\subsection{State Police}

It refers to the act of patrol system in a federation in which the constituents or federating units employs own security officers (police) for controlling, managing and watching over security arising issues within each territorial boundary. Aleyomi (2013) sees state police as "sub-national policing of a specified territory in a federation". It denotes decentralisation of the present security operations system and power from single authority of the federation. In practice however, it means that when the policing operations, command, logistics are controlled by federating units of government within their territorial boundaries, and not necessarily by the central authority as it is presently with the Nigeria's federation. In modern democracies such as US, Canada, Britain, Ethiopia etc, policing a federation have undergone a notable change that cut across the levels of government i.e. central, states/regions and local units of a federal system (Owen, 2014). However, state police are a requisite feature in governing a federation state by allowing the peripheral units to employ means of safeguarding its people's lives and properties within their states jurisdiction, provinces or districts (Owen, 2014). Consequently, introducing state police in Nigeria explains a departure from the status-quo of central policing system, funding and control of the Nigerian police force to give way for each federating units (states) to perform this duty within Nigeria's federal system.

Simply put, state police signify the absence of a single national police force as currently obtained under the supervision of the Inspector general of police (IG). With state police, state governors are to maintain laws and order through the state police force without interference of the Inspector general of police (IG) or president as the case maybe. Going by this argument, section 214 of 1999 constitution as amended which provides for policing the whole federation through a single police force by the central authority, must be amended. In addendum, section 215(3) of the constitution must also be altered to withdraw the directive power and authority of Mr president or the minister to the Inspector general of police (IG) on matters related to public safety as posited by (Kasali \& Odetola 2016). Similarly, the referral proviso of $\mathrm{Mr}$ president in a directive to the state governors through commissioner of police on public safety in section 214(4) must be deleted to give way for the creation of state police.

\subsection{History of the Nigeria's Police}

Prior to incorporation of the Nigeria state into the capitalist world economy, the various ethnic nationalities that comprises today Nigeria, had a separate workable mechanism through which it protects and enforces laws and order within its domain. In these various systems and in most often than not, social order is achieved though religious creed, natural law, secret cult, oracles, values, royal messenger (Ogunbiyi, 2018). However, the present police system in the country came into limelight around 1860, created by the colonial powers starting with 30 men 
consular guard in April 1861 for effective entrenchment of the colonial rules and policies within the Lagos metropolis (Fanran, 2018). In 1863, the name was changed to "Hausa guard". By 1879, the guards were regularised by ordinance of the colonial administration as the "constabulary of the Lagos colony" operating within Lagos alone. Furthermore, in January 1896, the structure and the name were further changed to "Lagos police force" expanding their operational functions beyond Lagos but south-west comprising the present south-western states. By 1891, the "constabulary guard of oil river protectorates region" was created with headquarter in Calabar present cross river state capital. In 1893, there was also creation of the "constabulary of Niger coast" to operate within the coastal line area with headquarter in Benin city present day Edo state (Fanran, 2018). In 1888, the "Royal Niger constabulary" by royal Niger company with headquarter in Lokoja was created to operate within Ilorin, Bida and Lokoja. In 1900, the Royal Niger constabulary was divided into two as "Northern Nigeria police force and the northern Nigeria regiment" to operate in the northern protectorate. By 1906, Johnson (2014) stated that the "southern Nigeria police force" was created from Lagos police force and part of constabulary of Niger coast; with the bulk of the constabulary Niger coast remained as "southern Nigeria regiments" to operate the southern Nigeria. Finally, April 1930 witnessed the unification of all these segments mentioned above into a single form called the "Nigeria police force" with mandate of jurisdiction to monitor/secure the Nigeria state (Fanran, 2018).

Johnson (2014) stated that various constitutional review in the country at pre and post-independence era i.e. 1951, 1954, 1979 and 1999 have consistently maintained that: "...there shall be a police force in the country which shall be styled as the Nigeria police force to be subjected to constitutional provisions of the Nigeria federation, with no other police force shall be established for the federation or any part there of'. Furthermore, in line with this proviso, section 4 of 1967 police Act spelt out the functions and modus operandi of the force to include: prevention and detection of criminal activities, apprehension of offenders, safeguarding of law and order, lives and property's protection, enforcement of all laws and regulations and performance of military duties within and outside Nigeria under authority or Act thereof Agawanwo (2014).

The above were the core basic functions of the Nigeria police force giving the constitutional proviso. However, looking at the size of the Nigerian state with estimate of about 180 million and a land space of 913,072.64 square kilometres, Iyang \& Abraham (2013) stated that there is need for constant and continuous review in the operation of the force to be able to discharge its constitutional functions. It is important here to note that the Nigeria police force is centralise system in structure and command of operation headed by an Inspector-General of police (IG) as the constitution of the federation started in section 215 (2) of the 1999 as amended that: "the force shall be headed and commanded by the inspector-General of police and the contingents of the force in the states be headed by a commissioner of police in that state subject to the authority of the IG" (Fanran, 2018).

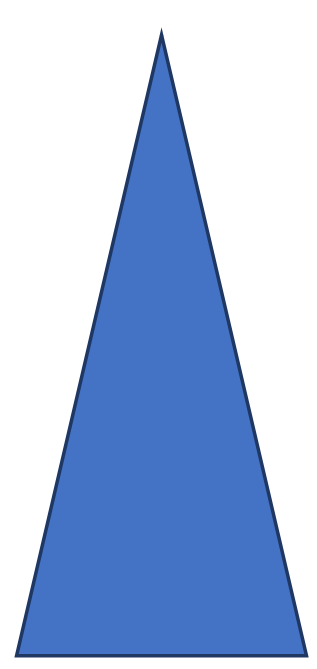

Inspector-General of Police (IGP) (highest rank)

Deputy inspector -General of Police (DIG)

Assistant Inspector-General of Police (AIG)

Commissioner of Police (CP) in-charge of state contingent

Deputy Commissioner of Police (DCP)

Assistant Commissioner of Police (ACP)

Chief Superintendent of Police (CSP)

Superintendent of Police (SP)

Asst. Superintendent of Police (ASP)

Inspector of Police (IP)

Sergeant Major (SM)

Sergeant

Corporal

Constable (Lowest Rank)

Designed by the author

As a diverse nation, Nigeria have structurally undergone series of political changes and development from independence in 1960 to date. Obidimma (2015) stated that, the structural changes have led to the gradual creation of states and local governments units from the inherited three regions at independence. The general cry and 
agitations for relative autonomy by the emerging needs from various communities made previous leaders to politically respond to these agitations thereby created states and local government units. For this reason, the Nigeria police force structure was centrally realigned to fit the security needs of the politically created units (states) in the country. Because of that, state police contingents/commissions were set up as well as five directorate units including: Administration and finance, operations, logistic and supply, investigation and intelligence as well as training and command in the headquarter were also created headed by Deputy Inspector-General (DIG's) (Owen, 2014). At local government level, the police restructuring has devolved power to police zonal command units from eight to twelve in 1999 (Akume \& Godswill, 2016).

\subsection{Constitutional Dilemma on State Police}

As earlier stated, the shouting for the creation of state police in Nigeria by dissolution of the present centralise policing was due to increase of hostilities, crimes and intolerance among the diverse Nigerian nationalities. However, Onyeozilli (2005) has earlier stated in line with Fanran, 2018, that the bone of contention and the dilemma in the constitution can be seen in section 214, subsection 1 of the 1999 constitution of the federation as amended that: "There shall be a police force for the federation as 'Nigeria police force' and no other police be created for the federation or any part thereof". Also, in Section 2, it stated that: "The force shall be under InspectorGeneral of Police and any contingent stationed in the states shall be subject to the authority of the InspectorGeneral (IG) to be commanded by state the commissioner of police". Additionally, in same section, the constitution stated that: "State governors may give the state commissioner of police lawful directives in respect to maintenance of law and order for public safety within the state when necessary, and the commissioner of police shall comply with the directives".

On the other hand, section 176 (2) of the 1999 constitution as amended states that: "the state governors shall be the chief executive officers of their respective states". Giving these two conflicting provisions of 214 and 176 (2) above, one could see that the governors being the chief executive and security officers in their respective states are made to be ceremonial heads regarding security in the state given the earlier provision in section 214 (2) which centralises the Nigeria police force states contingents units subject to the Inspector-General authority and not the state governor(s) who are the chief executive and security officers of their respective states. The complexities here is that the section 214 (2) above has reduced the power of the state governors as chief security officers of their states by subjecting the states police contingents command units to the order of the Inspector-General and relegated 176(2) powers of the state governors. This according to Ugwu, Ngige \& Ugwuanyi (2013) has made the heads of the police contingents units (i.e. commissioners of police) in the various states to be answerable only to the Inspector-General of police at the centre. 'They' the commissioners of police in the states are appointees of the IGP and not the state-governors who oversee the security affairs of the states, rendering the governors less important but the IGP.

Practical example of this constitutional dilemma and altercation could be reflected in river state between the then sitting governor Rotimi Ameachi as chief security officer of the state by virtue of section 176 (2), and the former commissioner of police in the state $\mathrm{Mbu}$ Joseph $\mathrm{Mbu}$, and all his principal officers who refused to be acknowledging any official correspondent from the governor as section 2 stated above the lawfulness of a governor to give directives to the commissioner of police when the need arises in matters related to public safety. Responding to this complain by the state police commissioner, Mr Mbu has cited section (2) of the 214 stating the constitutional provision for him (as state commissioner of police) to receive or act on the instruction of the IGP in policing the state.

\subsection{The Clamour for State Police}

However, the present resurgent call for state police in Nigeria is due to uprising of insecurity, terrorism and the spree killings between farmers and herders in different part of the country. The federal constitutions have specified the devolution of powers in its various sections, and the centralized police operation in Nigeria is a negation to the federal principles which have not been able to protect the citizens lives and property's due to large size of the country. The basic argument for the state police according to Odoshimokhe (2017) is to make the police servicing more effective and efficient and closer to the policing community who understand their languages, geographical terrain and security challenges of the policing community. Furthermore, as insiders, they will work assiduously with the serving community for effective policing within their constitutional parameter to enforce criminal laws made by the peripheral/states legislatures for maintenance of law and order. 
The continued agitations on the issue of state police has become a bone of contention in the polity with many commentators calling for it considering the dynamics of society and what is happening in Nigeria polity today given the raise of insurgency in the system. Today, Nigeria legally operates federal system in which power is constitutionally divided between the central and federating units, but with centralised policing system in functions and structure to defend the state constitution of the federation. The outcry by the agitators of state police system is to aid the practice of true federalism like other federating states such as the United States of America where Nigeria copy the model from (Fanran, 2018). State police system was earlier practiced in the 50s and the 60s when the country was peaceful and united in cohabitation of the various nationalities. For those Nigerians in the 50s and 60s, they were nationals to the core when the territorial boundary of the country was safe, and all Nigerians were also safe. But today, the story is different with the bastardisation of the cultivated unity of our forefathers. Though, the country is not at war but in different part, everywhere have become a war zone with insecurity at increase: insurgency of the Boko-Haram, militancy in the Niger delta, herdsmen ethnic militias, border porosity, cybercrime, kidnapping and armed robbery to mention a few (Odoshimokhe, 2017). Accordingly, the proponents of the idea argued that the system is necessary because it will bring security personnel closer to the people by enhancing whereabout knowledge of the police officers by the people within their area against the present centralised structure that is far from the people. That, the state police personnel will be more familiar with the people and cultural environment under their surveillance through daily interwoven (Fashola, 2013). The issue of state police has become big issue in the last national conference held in 2014 due to the crime increase and the larger size of the present Nigeria police force consisting 36 commands grouped into twelve zones and seven administrative organs to be controlled from the centre.

Another argument by the proponents is that giving the constitutional duties for the police force being closer to the people compare to other security outfit like the army, the police officers are not supposed to be far from the public and thereby need constant interaction with the people in maintaining law and order and be referred to in state of danger. Ochei (2018) has argued that most at times crimes are perpetrated by the local people which requires part of the local to police the area and not someone else transferred from different socio-cultural environment. Another reason for the re-visitation of state police by the proponents is the larger size of the Nigeria state to be effectively policed by the central authority, there will be gross inefficiency.

The UN guideline on police ratio to a giving community is 250 police personnel to 100,000 citizens, an approximate of 400 persons to a police officer (Owen, 2014). By relating this to Nigeria with the total figure of 370,000 police officers nationwide to police a population of approximately 200 million as at 2018 , equivalent to 540 persons to a police officer, one could argue that the Nigeria police force (officers) are inadequate hence there need for the state police to meet up with the UN guideline. This situation has justified the creation of state police in addition to the rising trend of insecurity in developing world of Africa with Nigeria as example beyond the developed nations which the UN came up with the findings from. Owen (2014) further argued that security control and crimes reduction vary from one country to another. In Nigeria for instance, the way kidnapping has gone high in recent time, state policing knowing the people and the environment will assist in reducing the situation to a barest minimum level.

\subsection{Opinion against the state police}

On the other hand, the call for the creation of state police has continued receiving criticism been part of restructuring agenda. Prominent Nigerian citizens both serving and retired Inspector- General of police such as Ibrahim Idris and Sunday Ehindero (rtd) and many of the northern governors have championed the criticism. The former president Goodluck Jonathan was quoted to have said that "the idea of state police is theoretically good for the country, but giving the political environment in the country, it could be abused" (Nwogwugwu \& Kupoluyi, 2015). We are not being able to develop a culture that could allow the implementation of state police. Today in Nigeria, politicians and political control of the police has impacted negatively in the operation of police force and their overall efficiency that has eroded nationalism and efficiency. It also destroys the morale for lack of good culture and discipline to produce good governance by been parochial and partisan. Until we can develop a good political culture and discipline devoid of regionalism and ethnic loyalty where we all believe in Nigeria and not parochial or ethnic sentiments to create rightful atmosphere for workable state police in the country (former IGP, TVC News Nigeria July 2016).

Furthermore, Kasali \& Odetola (2016) stated that many states governments cannot promptly pay salary of their civil servants i.e. teachers and health workers for months, and police funding is a capital intensive, if teachers and health 
workers could be owing salary from state government, how could the states be able to fund police organisation that is technologically driven equipment's. If the state police go on strike for six hours as teachers frequently experienced, the state will collapse. Accordingly, until states become economically viable to be able to fund the capital expenses of policing.

Given the UN guideline on the number of police officers to a given population recommending a minimum of 250 officers to police 100,000 people, by implication it means that 1 police officer is to police every 400 people. In Nigerian today giving the report on the strength of Nigeria police by 370,000 as of 2012, (between that time and now, there could be an increase due to the ongoing recruitment), given this scenario, the gap differences in what is obtainable presently in Nigeria is insignificant and therefore the call for the creation of state police because of inadequacy is not justifiable?

According to Akum (2016), if not because of the present situation of political disposition and the IQ of our politicians, state police would have been the best ideal for the country. Furthermore, it is not about the number of the police officers that matters but how well are they equip giving sophistication of today's crimes driven by technology. For instance, the issue of kidnapping does not require the number of police officers to rescue the victims but the technology to track the kidnappers. Therefore, funding policing by states government cannot well equipped, motivated and trained police officers to their capacity. The number also is a problem, but the police are third maintenance security, the police are involved in all issues of crimes, so, technology driven policing is the answer not state police (Akum, 2016).

Furthermore, the state governors pushing for state police might want to use the police officers under them to affront political opponents giving the political immaturity among the politicians. Example of this could be seen where governors uses the present federal policing to demolished people's houses and shops. Moreover, the politicians at the state level may end up employing political thugs and party members as police officers to continue brandishing power and humiliation against their political opponents (Innocent \& Ogbochie, 2014). Unless if there should be a strict legal structure to make them independent of the governors control different from what we have now, it will be abused.

In a similar vein Obidinma (2015) stated that, state police are achievable only if the constitution is amended, and by doing so, there will be multiplicity of police force in the country with different laws that may contradict one another hence difficulty in coordination. We should not go by a wholesale importation of models from other political climate like US and Canada and expect it to work in our system. What the governors want is absolute power of control Obidinma added.

\section{Discussions and Recommendations}

The damning reports from within and outside the country on the high toll of deaths is approximately over 50,000 people as reported by Nwogwugwu \& Kupoluyi (2015) from 2011 to date is worrisome. In Nigeria today, one can see how little value human lives have compare to the oil commodity. The question to ask here is that, "is state police a solution to the current security challenges in the country? For me, the answer is no giving the preceding arguments for and against. For the mere fact that the Nigeria police is decentralise will not directly stop the challenges looking at it from wider perspective of multiple factors that causes insecurity in the country. One of the important things to note in dealing with the insecurity to improve police efficiency should be seen from two dimensions: geography and history. Geographically, if society fails to understand its geographical terrain to know the axis and exit points, such a country will be badly beaten up in trade and security. Lack of clear understanding of the nation's geographical security terrain to enable them effectively to plan for trade and security is a major challenge in Nigeria. Most of the attacks heating various communities in different part of the country keeps on occurring and coming from the people that seems to know and understand the terrain very well.

Moreover, there is underutilisation of intellectual resources in the country by not using enough geographers to strategies on the vulnerable point. Secondly, one also must understand the historical antecedents of the vulnerable areas and why the crisis tends to proliferate? The moment such things are understood resources could be easily channelled where it will yield a highest return. Moreover, we need to understand that we are not only dealing with a local problem (insecurity) but rather a regional and continental problem. The deepest crisis faced in the African continent today comes from the Sahel region where Nigeria is bounded to such countries: Niger, Chad, Mali and Burkina Faso. Looking at the human index in those countries, there people moves around unchecked and could do 
anything to earn a dollar. They are frustrated not only by poverty, but also climatic changes taking the advantage of the porous borders of Nigeria to come in.

Going by history, Nigeria has practiced state police on regional bases under the 1963 constitution. In 1966, with the incursion of military into governance, the led General Aguiyi Ironsi military government set up a Gobir commission to deal with the perception problems of the regional police. The idea identified by the commission was that the regional police (state police) of that time were over bearded and most often used against people and the opposition. Many people argued that it was the political manipulation of the regional police that led to the 1966 coup in the first place. So, the Gobir commission at that time recommended for national police (Fanran, 2018).

The real problem is that of section 214 of the 1999 constitution as explained earlier which put police under individual and not an institution. The police were relegated to the discretion of one-man as provided by the constitution, which made them not to work as an institution.

Ideally, the police should be under the justice system i.e. Attorney General to bring the nexus and technically made them answerable to justice system. If the police need to arrest criminal, they need to have a warrant from a judge. This will made them to govern by rule of law and not by an "Order" of the president or the governor as provided in section 214 of the constitution. This is the reason why the police service in the country is militarise with high level of political interference.

Furthermore, security operations require innovations and imagination to tackle the growing insecurity rather than the proliferation of security agencies such as EFCC, ICPC, DSS, Civil defence etc which might not be too good for the security effectiveness in Nigeria (Iyang \& Abraham 2013). This is because the agencies became duplicated in functions and the funds that are supposed to be pumped to equip, train and motivate police force to be efficient and effective capacity have now been diverted to other similar agencies thereby reducing the power and funding of the police.

The negative perception of trust by the public on the Nigeria police force was inherited from the brutal colonial era of police system against the people commanded by the colonialist to serve their interest (Odoshimokhe, 2017). After independence, the long military rule in the country that came with decree 2 and 4 further militarises policing by enforcing laws not palatable to the people, and the public see police as government agents against their wish. So, until the public begin to see the police as 'theirs', and recruitment/promotion is not by tribal or sectional but performance. Additionally, Ogunbiyi (2018) stated that citizens also have a role to play based on the Rousseau concept of social contract as section 14 (b) of the constitution stated that: "the safety and welfare of citizens is the prime-purpose of government" and section 24 of the constitution says that: "every Nigerian citizen has a duty to assist the police in maintenance of law and order". But today in Nigeria, citizens don't see that as their obligation rather they alienated police instead of working together through unity of action and thought.

Another factor to improve police efficiency is to have the right political culture and maturity by politicians and the citizens that will gradually develop in the long run of democratic system. How old is Nigeria's democracy today compare to US for us to have a right political culture and maturity? Nigeria is less than 20 years in democratic system, while US is over 200years (Ohayi, 2018). Therefore, Nigeria's democracy is at the adolescent stage of growth and development. Police operation is influenced by social and political milieu which right now the environment is not ripe for state police. Until patriotization and national culture is developed.

If state police are to go by, their salaries and remunerations should be deducted direct from the sources to avoid salary backblock by the state governments. And the constituted police council/service commission for each state should constitute representatives from Nigerian Bar Association (NBA) and members of civil society's to be nominated by their organisations and not the state governors.

Lastly, Nigeria police should operate federal system by decentralising its power of command and authority from the Inspector-General at the centre. The state governors should have a power of command been the security officers in their respective states. 


\section{Conclusion}

From the foregoing discussions, it is evident to say that policing a state requires the socio-cultural knowledge of the environment giving the fact that crimes are perpetrated by the locals and therefore needs the local inputs to tackle the situation. Centralization of police commands and authority is in no doubt a set back to their performance. Also, section 214 of the constitution need to be revised to distance police institution from political control. Right political culture and maturity is needed before state policing is introduce.

\section{References}

Adedeji, O. A. (2012). State police in Nigeria: Issues and Challenges.

Adefi, O. M., \& Achor, A. J. A. (2013). Re-Awakening the State Police Controversy in Nigeria: Need

Rethink. International Journal of Asian Social Science, 3(11), 2307-2314.

Agawanwo, D. E. (2014). State policing and police efficiency in Nigeria. Research on Humanities and Social Sciences, 4(25).

Akume, A. T., \& Godswill, J. (2016). The challenge of managing insurgency in Nigeria (20092015). Mediterranean journal of social sciences, 7(1 S1), 145.

Aleyomi, M. B. (2013). Is State Police A Panacea to Security Threat In Nigeria? Afro Asian Journal of Social Sciences, 4(4.2).

Eme, O. I., \& Anyadike, N. (2012). Security Challenges and the Imperatives of State Police. Review of Public Administration \& Management, 1(2). https://www.arabianjbmr.com/pdfs/RPAM_VOL_1_2/15.pdf

Fanran, A. O. (2018). The propose state police and the language: Panaceas for insecurity in Nigeria. European journal of English language and literature vol. 5(1).

Innocent, E. O., \& Ogbochie, A. N. (2014). Limitations of State Police in Nigeria. Mediterranean Journal of Social Sciences, 5(15), 130.

Inyang, J. D., \& Abraham, U. E. (2013). Policing Nigeria: A case for partnership between formal and informal police institutions. Merit Research Journal of Art, Social Science and Humanities, 1(4), 53-58.

Inyang, J. D., \& Abraham, U. E. (2013). Policing Nigeria: A case for partnership between formal and informal police institutions. Merit Research Journal of Art, Social Science and Humanities, 1(4), 53-58

Johnson, I. (2014). Policing in Contemporary Nigeria: Issues and Challenges. African Journal for the Psychological Studies of Social Issues, 16(1), 71-77.

Kasali, M. A., \& Odetola, R. G. (2016). Alternative Approach to Policing in Nigeria: Analyzing the Need to Redefine Community Policing in Tackling the Nation's Security Challenges. African Journal of Criminology and Justice Studies: AJCJS, 9(1), 98.

Nwogwugwu, N. \& Kupoluyi K. A. (2015). Interrogating the Desirability of State Policing In Nigeria. Journal of Humanities and social science Volume 20(5).

Obidimma, A. E., \& Obidimma, E. O. (2015). State Police an Imperative for True Federalism in Nigeria. International Journal of Innovative Research and Development, 4(11).

Onyeozili, E. C. (2005). Obstacles to effective policing in Nigeria. African Journal of Criminology and Justice Studies: AJCJS, 1(1), 32.

Owen, O. (2014). The Nigeria Police Force: Predicaments and Possibilities. London: Nigeria Research Network. http://www.qeh.ox.ac.uk/sites/www.odid.ox.ac.uk/files/nrn-wp15.pdf

Ugwu, C. E., Ngige, D., \& Ugwuanyi, B. (2013). Calls for State Police In Nigeria: Options For S ustainable National Security

Odoshimokhe, M. (2017). Who is afraid of state police? The nation, August 24 http://thenationonlineng.net/afraid-state-police-2/

Aremu, O. (2018). State police: challenges and security realities. Punch, July 13

http://punchng.com/state-police-challenges-and-security-realities/

Abatti, R. (2010). State police and the challenges of Internal security. The Nigerian Voice, July 7

https://www.thenigerianvoice.com/news/26207/state-police-and-the-challenges-of-internal-security.html

Ogunbiyi, T. (2018). Revisiting the state police debate. PM News, July 20177

https://www.pmnewsnigeria.com/2017/07/22/revisiting-state-police-debate/

Ochayi, C. (2018). $61 \%$ of Nigerians endorse creation of state police. Vanguard, February 201821 
https://www.vanguardngr.com/2018/02/61-nigerians-endorse-creation-state-police-survey/ Enogholase, G. \& Obetta, O. (2012). State Police: To be or not to be. Vanguard, August 201225

https://www.vanguardngr.com/2012/08/state-police-to-be-or-not-to-be/

Enehikhuere, J. (2017). State Police: Addressing the fears and challenges. The News, July 201720

http://thenewsnigeria.com.ng/2017/07/state-police-addressing-the-fears-and-challenges/

Ochei: Why Nigeria needs state police. The Pointer http://thepointernewsonline.com/?p=26297

Ehindero, S. (2018). Wither Nigeria: National or State Police? Vanguard, February 201822

https://www.vanguardngr.com/2018/02/wither-nigeria-national-state-police/

Fashola, B. (2009). Security and Good Governance: The Imperative of state police at Arewa youth forum Award for Excellence in Governance.

http://www.tundefashola.com/archives/news/2009/12/05/20091205N01A.html

Benjamin, O. A. (2016). A case for state police in Nigeria: What is the way forward? https://fridayposts.com/casestate-police-nigeria-way-forward/

CREATION OF STATE POLICE FORCE IN NIGERIA: PROS, CONS AND A WAY FORWARD

http://bestresearchprojects.blogspot.com/2013/12/normal-0-false-false-false-en-us-X-none.html

[TVC News]. (2016, Jul 21). State police: To be or not to be? [Video file] retrieve from https://www.youtube.com/watch?v=5xbFP2qURCM 